\title{
Effect of University Entrance Exam on Gifted High School Students' Motivation Scrutinized: An Iranian Perspective
}

\author{
Ali Kazemi (Corresponding author) \\ Department of English \\ School of Humanities, Yasouj University, Yasouj, Iran \\ E-mail: akazemi@yu.ac.ir \\ Ali Sayyadi \\ School of Humanities, Yasouj University, Yasouj, Iran \\ E-mail: ali.sayadi1998@gmail.com
}

Received: 07-04-2014

doi:10.7575/aiac.ijalel.v.3n.5p.150
Accepted: 11-05-2014

Published: 01-09-2014

URL: http://dx.doi.org/10.7575/aiac.ijalel.v.3n.5p.150

\begin{abstract}
Passing University Entrance Exams (UEE) successfully has long been a major concern for Iranian high school students. High Schools for the Gifted admit highly intelligent and hardworking students, who reportedly form a remarkable proportion of students admitted in best universities of Iran, through hard entrance exams. This study aimed to investigate attitudes of students educating in High Schools for the Gifted towards learning English, their dominant motivation type (instrumental or integrative), and the likely effect Iranian University Entrance Exam has on their motivation. For the purpose of this investigation, 166 male and female participants educating in the four grades of high school were selected through Stratified Random Sampling Method from both boys' and girls' High Schools for the Gifted. A 26-item questioner previously developed by the researchers, investigating the participants' attitudes towards English learning, their dominant motivation type, and the likely effect of Iranian UEE on their motivation was administered to them. Descriptive statistics and the analysis of variance were used to analyze the data, and the results revealed that all participants educating in the four grades of high school showed positive attitudes towards English learning, and that $1^{\text {st }}$ and $2^{\text {nd }}$ grade subjects were both instrumentally and integratively motivated, whereas $3^{\text {rd }}$ and $4^{\text {th }}$ graders were instrumentally motivated. The degree of subjects' concern about the Iranian UEE significantly affected their motivational orientations and prioritization.
\end{abstract}

Keywords: Motivation, Interest, Instrumental, Integrative, University Entrance Exam, Gifted Students

\section{Introduction}

Many pertinent conditions should be provided in order for successful second or foreign language learning to take place, but most teachers and researchers would agree that motivation is one of the key factors that determine learning achievement; therefore, defining and exploring L2 motivation and researching the characteristics of motivated learners have traditionally occupied an important place on the research agenda of both applied linguists and language educators (Csizer et al., 2006). Long pervasive arguments have been put forward to suggest that motivation is one of the pivotal issues in language teaching and learning, and that motivating language learners should be of high priority for language teachers. Many different definitions have been offered for the term 'motivation', yet its meaning is still vague, and is best seen as a broad umbrella term that covers a variety of meanings (Dörnyei, 2001). It has been defined as "the driving force to sustain the long and often tedious learning processes" (Rutledge Encyclopedia, 2000, p.425), and is "what moves a person to make certain choices, to engage in action, to expend effort and persist in action" (Dörnyei\& Ushioda, 2010, p.3). It is perhaps the only intake variable that has been consistently found, in various contexts and at various levels of L2 development, to correlate positively with successful learning outcome (Kumaravandivelu, 2006). "Motivation is, without question, the most complex and challenging issue facing teachers today" (Scheidecker\& Freeman 1999:116).

Different modes and frameworks have been proposed for motivation. For instance, the social psychologists, Garden and Lambert (1972), offered instrumental and integrative motivations as different types of motivation. On the other hand, three types of motivation have been proposed by cognitive psychologists: intrinsic, extrinsic, and achievement motivation. Meanwhile, Dörnyei (1994a), who took Crookes and Schmidt's approach of examining motivation at various conceptual levels, conceptualized L2 motivation whining a framework of relatively distinctive levels: language 
level, learner level, and learning situation level ( see Dörnyei, 2006). Brown (2007) illustrated the relationship between the two dichotomies of instrumental/integrative and intrinsic/extrinsic motivation, as illustrated in the following table:

Table 1. Motivation dichotomies taken from Bailey

\begin{tabular}{lll}
\hline & \multicolumn{1}{c}{ Intrinsic } & \multicolumn{1}{c}{ Extrinsic } \\
\hline $\begin{array}{l}\text { integrate } \\
\text { Integrative }\end{array}$ & L2 learner wishes to & $\begin{array}{l}\text { Someone else wishes the L2 learner } \\
\text { to know the L2 for integrative reason } \\
\text { (e.g., Japanese parents send kids to }\end{array}$ \\
& $\begin{array}{l}\text { with the L2 culture (e.g., for } \\
\text { immigration or marriage) }\end{array}$ & $\begin{array}{l}\text { Japanese-language school) } \\
\text { External power wants L2 learner } \\
\text { Instrumental }\end{array}$ \\
& $\begin{array}{l}\text { L2 learner wishes to achieve } \\
\text { goals utilizing L2 (e.g., for a } \\
\text { career) }\end{array}$ & $\begin{array}{l}\text { to learn L2 (e.g., corporation } \\
\text { sends Japanese businessman to } \\
\text { U.S. for language training) }\end{array}$ \\
\hline
\end{tabular}

Although the old characterization of motivation in terms of integrative versus instrumental motivation is too static and restricted (Gardner \& Macintyre, 1993), most studies on motivation have been inspired by the distinction between instrumental and integrative motivation (Kumaravadivelu, 2006).

Integrativeness, on the other hand, is highly reflected in learners who seek to learn a new language in order to integrate themselves into a new culture and have social communicative interchange with the second language group. The growth of individuals who are learning another language in their own country in order to partake in global or regional exchanges is an indication of foreign language learning through integrative motivation (Long\& Doughty, 2009). Many studies have attached great importance to integrative motivation and have confirmed its association with predicting perceived competence, perceived autonomy, persistence, lower anxiety, and positive attitudes towards language learning (see Clement et al., 1994; Ehrman, 1996; Noels et al., 1999, 2000, 2001; Ramage, 1990; Tachibana et al., 1996). It is also theorized that "integrative motivation typically underlies successful acquisition of a wide range of registers and a native like pronunciation" (Finegan, 1999, p. 568).

Many studies undertaken on the motivations of language learners have proved the fact that, depending on learners' needs and also on the context in which they are, language learners might be instrumentally or integratively motivated. Although in recent language designs communication and interaction are regarded to be the main goals of language learning, there might be some learners who would be, by no means, interested in learning a second language to communicate. They would intend, for instance, to read extensively in an L2 and need to recognize a lot of words that they may never have to use themselves (Wharton\& Race, 1999), and passing a course or getting accepted in a university might be their only goal to learn new vocabulary.

The social context of language learning and teaching is greatly impacted by a nation's political decision to give special status to a particular language or languages. This status can be achieved either by making a language an official language of a country or by giving special priority to the language by requiring its study as a foreign language (Long\& Doughty, 2009). After Islamic revolution in Iran (1979), Arabic was considered as the dominant foreign language to be learned by the students educating in junior and high schools. Still, since the value of a particular language, as Long and Doughty (2009) believed, is often undermined by the prevalent social beliefs, English found its true place among people after a while and learning it became a pivotal task. In order to enable students to read English books published in Iran, schools provided about 540 hours of English courses in guidance and high schools (Eslami Rasekh, 2012) focusing on academic objectives rather than communicative ones. Therefore, students were mostly extrinsically motivated and instrumentally oriented to learn English as a foreign language. Founding many language institutes which used text books designed for communicative purposes by native specialists, and also the growing need to learn to communicate in English as the dominant lingua franca made a change in language learners' orientation and motivation, and since then students have been learning English with different orientations and motivations.

Higher education is one of the most important concerns of Iranian students because of the essential role it has in their occupational and social lives, and the University Entrance Exam (UEE) in Iran, known as the "Konkoor", is the only qualification criterion to select students to educate in higher education. As a competition test, the UEE has often imposed stressful educational years on students due to the fact that they need to compete with other applicants in order to be admitted in universities. Even students with high integrative motivation might change views about learning English as they are approaching the UEE day. English questions form a remarkable proportion of general questions in University Entrance Exams, and answering them correctly will facilitate applicants' acceptance in more prestigious universities. Absence of functional-communicative tests in UEEs would make applicants forget interactive and communicative functions of language and concentrate, instead, more on instrumental objectives accomplished by focusing on language elements in isolation and integration. 
Students educating in the grade after third grade of high school used to be long called "Pre-university students" in Iran. However, "Pre-university" grade has changed name to "fourth grade" of high school. Students educating in fourth grade of high school almost study the same courses which used to be offered in pre-university grade; hence a nominal shift is the only change which has happened to pre-university grade.

Secondary and High Schools for the Gifted are centers which admit students with higher IQ levels to educate. Volunteers who tend to educate in such schools need to pass a National Entrance Exam. Students educating in the Schools for the Gifted are believed to be more hardworking and studious. They are also said to receive a higher level of instruction as well as more various extra-curriculum educational programs and books in comparison to their peers in other schools. As a matter of fact, they form a remarkable proportion of students who find the chance to continue their education in better universities and majors after passing the Iranian UEE. The present study aimed to investigate motivation of Iranian male and female high school students in High Schools for the Gifted in Yasouj. It also aimed to investigate the likely effect University Entrance Exam would have on their goals and motivations.

\section{Literature Review}

The significance of taking language learners' motivation into consideration before developing any course has necessitated conducting numerous studies on the types of language learners' and motivation as well as on their role in language learning in an EFL context. Various researchers in Iran have tried to study the attitudes of the learners towards English learning along with the dominant type of motivation among them and found inconsistent results. Some of the motivation-based studies conducted in Iran indicated that Iranian language learners had very high motivation and positive attitudes towards learning English, and also they were more instrumentally motivated (see Gholami et al., 2012; Mehrpour \& Vojdani, 2012; Sheibani, 2012; Vaezi, 2008). This is in line with the concept of EFL learners' motivations defined by Dörnyei (1990) and Oxford (1996) who believed that in EFL context, where learners have not had sufficient experience of the target language community, instrumental motivation should receive special attention and be a main focus for research in EFL context. As an example, Gholami et al. (2012) investigated the performance of 95 Iranian EFL students in the 3rd grade of high school to determine which motivation type dominates among them and also to find out the motivation type of high achievers. The research findings indicated that the dominant motivation type among their subjects was the instrumental orientation, and also high achievers in this study were mostly integratively oriented. On the other hand, some researchers such as Sayadian and Lashkarian (2009) and Sadighi and Maghsudi (2000) showed that although some learners learn English in Iran for instrumental reasons, the integrative motivation was the dominant motivational orientation for the subjects of their studies. For instance, in a survey on 500 Iranian university students to examine their attitudes toward English learning, Sayadian and Lashkarian (2009) suggested that integrative motivation was the dominant motivation type among their subjects and students with instrumental orientations did not form a remarkable proportion of the participants in their study. However, some researchers such as Moiinvaziri (2008) and Ebrahimi (2002) claimed that the participants in their studies were highly motivated both instrumentally and integratively. Such findings indicate that there is no single means of learning a second or foreign language, and that in the same context of language learning, some learners are more successful in learning a new language if they are instrumentally motivated and some others may facilitate their language learning if integratively motivated. Thus, it could be seen that the results of the studies conducted on motivational orientations in Iran bore mixed results.

The type of motivation language learners have affects their language proficiency differently, and also the way language learners think of their abilities in language is effective in forming their motivation to learn a language in an EFL context. Zeraat Pisheh and Ghanea (2011) studied the relationship between the motivation of language learners and their language proficiency on 128 college students majoring in English. The results of their research revealed that there was a significant relationship between integrative and instrumental motivation with language proficiency of learners.

In countries like Iran where University Entrance Exams have often been administered after students' graduation from high school as the sole criterion for university admission, various studies have been carried out on the effects of UEEs on educational and instructional issues. Briggs (2001), for instance, studied the effects of admission tests for university and concluded that standardized university admission tests are more than a one-shot deal. Such tests are blind to a student's high school record; instead, they are intended as an independent, objective measure of college "readiness". In his opinion for students with a strong high school record, admission tests provide a way to confirm their standing, and for students with a weaker high school record, admission tests provide a way to raise their standing. Furthermore, Basturk (2011) investigated negative effects of preparation process of the university entrance exam on students' mistakes related to the function concept. The results of his study showed that preparation process of the entrance exam had negative influences on student learning in mathematics. Salehi and Yunus (2012) examined the effect of Iranian University Entrance Exam on Iranian high school teachers in Isfahan. They administered a questionnaire to a stratified random sample of 132 high school English teachers who were teaching in the five main educational districts in the city of Isfahan, Iran and concluded that UEE negatively and implicitly influences English teachers to teach to the content and format of the test. In another study, Wei (2012) researched on Vietnamese high school students and claimed that the 
University Entrance Exam in Vietnam demotivated students to do any deep learning and forces them to memorize knowledge rather than create their own ideas, and also it stops them from thinking critically. Lack of consistent findings about the likely effect of Iranian UEE on the motivational orientation of Iranian high school students, especially for gifted students called for revisiting the issue in the Iranian context.

\section{Statement of the problem}

Limitations in admission of students in universities in Iran as well as difficulties in continuing education in favorite fields of study have led to emergence of a tough competitive atmosphere among Iranian high school students. Engineering and medicine have long been the most favorable majors among Iranians, and high school students often prefer to continue their education in these majors. Of course the establishment of numerous universities in various areas of Iran has somehow solved the problem of entering universities, and Iranian UEE does not have the strong view of "fail or pass" in applicants' eyes, as it used to have. However, the chance to educate in better universities in favorite majors has still kept the competitive atmosphere of UEE alive because students who graduate from better universities would be offered better occupational opportunities. Therefore, being accepted in more prestigious universities is one of most important concerns of Iranian high school students. The English questions included in Iranian UEE are discretepoint (vocabulary and grammar questions) and integrative (cloze test and reading), and overlooking functionalcommunicative tests may change students' motivation in learning English. Students educating in High Schools for the Gifted are believed to be highly intelligent and prosperous in their academic lives. Therefore, finding out whether they are motivated enough to learn English and also identifying the dominant type of motivation they have along with examining the likely effect of Iranian UEE on their motivation, which have not already been studied, convinced the researchers to conduct such a study.

\section{Aims and Objectives}

In this study an attempt has been made in this study to find appropriate answers to the following questions:

- Are students educating in High Schools for the Gifted interested enough to learn English?

- What is the dominant motivation type among Iranian students educating in High Schools for the Gifted?

- Are there any differences among students in different grade levels in terms of type of motivation?

\section{Methodology}

\subsection{Research Design}

The current study sought to shed light on the English learning attitudes and motivations of students educating in High schools for the Gifted in Yasouj, Iran. For the purpose of this non-experimental quantitative study, the descriptive research method was adopted. Furthermore, the analysis of variance (ANOVA) was run in order to indicate whether there was any significant difference among the four groups of the subjects in terms of their attitudes and motivation.

\subsection{Participants}

The study was conducted at both boys' and girls' High Schools for the Gifted in Yasouj, Iran. In order to have a clear comparison of students' orientations educating in different levels, and also to take the proportion of the subjects in the population into account to have almost equal percentages of participants from each grade, 166 subjects were selected from among 297 students educating in both high schools in different grades and fields through Stratified Random Sampling method. Sample size was determined through Morgan's Table for Determining a Sample Size from a Given Population. Table 2 summarizes demographic information about the participants.

Table 2. Demographic information about participants

\begin{tabular}{lcccc}
\hline $\begin{array}{l}\text { Grade } \\
\text { Female }\end{array}$ & \multicolumn{2}{c}{ Population } & Sample & Male \\
\hline $1^{\text {st }}(\mathrm{M} \& S)$ & 77 & 43 & 22 & 21 \\
$2^{\text {nd }}(\mathrm{M} \& S)$ & 69 & 39 & 17 & 22 \\
$3^{\text {rd }}(\mathrm{M} \& S)$ & 77 & 43 & 21 & 22 \\
$4^{\text {th }}(\mathrm{M} \& S)$ & 74 & 41 & 17 & 24 \\
Total & 297 & 166 & 77 & 89 \\
\hline Note. $M=$ Mathematics: $S=$ Science & \multicolumn{4}{l}{}
\end{tabular}

\subsection{Instrumentation}

For the purpose of the study, a primary questionnaire of 60 items was developed through review of literature, whose items were generated through review of literature and consultation with experts in the field. Some of the items were taken from Gardner's Attitude/Motivation Test Battery (AMTB) (Gardner, 1985) and also from an extensive review of literature. In addition, the researchers added some items to suit the specific context of the project. In order for likely poor English proficiency of participants not to affect their accuracy in responding to items, all of the items were generated and rendered into Farsi, the participants' first language. The questionnaire was also observed by 10 TEFL 
university teachers to establish its content validity. As the result of feedback received, some revisions were made and the questionnaire was assembled with 40 items. Then, it was piloted with 25 high school students with similar characteristics to the intended participants. The primary internal consistency of items, estimated through Cronbach's formula, "coefficient alpha", was 0.61. Construct validity of the questionnaire was established through factorial analysis, as the result of which 14 items were deleted for various reasons. With a decrease in the number of items from 40 to 26 , through factor analysis, the internal consistency amounted to 0.75 . The final questionnaire was a 6-point scale rating from 'Strongly Disagree' to 'Strongly Disagree', and they were coded as Strongly Disagree=1, Disagree=2, Slightly Disagree=3, Slightly agree=4, Agree=5, Strongly Agree=6. It investigated the amount of motivation among Iranian EFL learners, instrumentality and integrativeness, and also the likely effect of Iranian UEE on high school students' motivation. The items of the questionnaire are modes of 4 different components which are as follows:

Component 1: The items investigating the subjects' interest in learning English

Component 2: The items investigating integrativeness of students

Component 3: The items investigating instrumentality of students

Component 4: The items investigating UEE effect on motivation of students in learning English

\section{Result and Discussion}

In order to answer the research questions, the obtained responses of participants were entered into the Statistical Package for Social Science (SPSS) 21 software. The students' responses were analyzed in terms of frequency and descriptive statistics. The obtained data was basically based on frequencies, hence the percentages were calculated. The frequency of students' response to each question was calculated separately to represent an in-depth analysis of research questions about the student educating in the four grades. The minimum possible score for the rates in following tables is 1 (Strongly Disagree), and the maximum one is 6 (Strongly Agree).

\subsection{Component 1, Interest in learning English}

Table 3 indicates the descriptive statistics for questionnaire items on Component 1, participants' interest in learning English. It depicts $1^{\text {st }}$ grade students' responses to the items.

Table 3. Descriptive statistics for Component $1,1^{\text {st }}$ grade participants

\begin{tabular}{|c|c|c|c|c|c|c|c|c|c|}
\hline \multirow{7}{*}{ 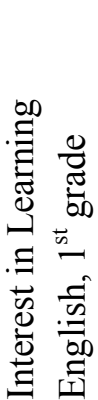 } & Item & STD & $\mathrm{D}$ & SLD & SLA & $\mathrm{A}$ & STA & Mean & SD \\
\hline & 11 & 0 & 1 & 2 & 7 & 11 & 22 & 5.19 & 1.02 \\
\hline & 16 & 0 & 0 & 4 & 6 & 14 & 19 & 5.12 & 0.98 \\
\hline & 20 & 0 & 0 & 1 & 4 & 16 & 22 & 5.37 & 0.75 \\
\hline & 22 & 0 & 0 & 3 & 4 & 14 & 22 & 5.28 & 0.90 \\
\hline & Total & 0 & 1 & 10 & 21 & 55 & 85 & 5.24 & \\
\hline & & $0 \%$ & $0.5 \%$ & $5.8 \%$ & $12.2 \%$ & $32 \%$ & $49.5 \%$ & & \\
\hline
\end{tabular}

Note. STD = Strongly Agree; $D=$ Disagree; $S L D=$ Slightly Disagree; $S L A=$ Slightly Agree $; A=$ Agree; $S T A=$ Strongly Agree.

Table 3 indicates that $93.7 \%$ of students in $1^{\text {st }}$ grade of high school agreed that they were interested in learning English. The overall mean of 5.24 also confirms their being zealous in learning English. In other words, they attached great importance to English learning (Item11) and claimed that they would learn English even if they did not plan to live in or have a journey to other countries where English is spoken as the first or second language (Item 16). For Item 20, almost all of the respondents wished they could watch English movies without any need for Persian subtitles, which represents their high interest in learning English. Table 4 investigates the same component about $2^{\text {nd }}$ grade participants

Table 4. Descriptive statistics for Component $1,2^{\text {nd }}$ grade participants

\begin{tabular}{|c|c|c|c|c|c|c|c|c|c|c|}
\hline & $\begin{array}{l}\text { Item } \\
\text { STA }\end{array}$ & STD & & $\mathrm{D}$ & & SLD & $\overline{\text { SLA }}$ & $\bar{A}$ & Mean & SD \\
\hline \multirow{7}{*}{ 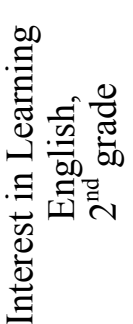 } & 11 & 0 & 0 & & 1 & 5 & 10 & 23 & 5.41 & 0.81 \\
\hline & 16 & 0 & 0 & & 5 & 8 & 7 & 19 & 5.03 & 1.11 \\
\hline & 20 & 0 & 0 & & 2 & 6 & 8 & 23 & 5.33 & 0.92 \\
\hline & 22 & 0 & 0 & & 2 & 9 & 13 & 15 & 5.05 & 0.91 \\
\hline & Total & 0 & 0 & & 10 & 28 & 48 & 70 & 5.20 & \\
\hline & & $0 \%$ & & $0 \%$ & & $6.4 \%$ & $18 \%$ & $30.7 \%$ & & \\
\hline & $44.9 \%$ & & & & & & & & & \\
\hline
\end{tabular}


Like $1^{\text {st }}$ grade subjects, students in second grade of high school showed a high level of interest in learning English (93.6\%). The high overall mean (5.20) of students' rates of the questionnaire items on the interest in learning English indicates how eager they are to learn English. For Item 11, nearly all of $2^{\text {nd }}$ grade participants agreed on the necessity of learning English. Item 16 received the lowest degree of agreement $\left(\bar{x}_{16}=5.03\right)$ ) among the items investigating the language learners' attitudes towards English learning; however, it is high by itself. It indicates more than $88 \%$ of second grade participants claimed even having no plans for traveling abroad would not prevent them from learning English. Table 5 shows how $3^{\text {rd }}$ grade subjects responded to the items on Component 1.

Table 5. Descriptive statistics for Component $1,3^{\text {rd }}$ grade participants

\begin{tabular}{|c|c|c|c|c|c|c|c|c|c|}
\hline \multirow{7}{*}{ 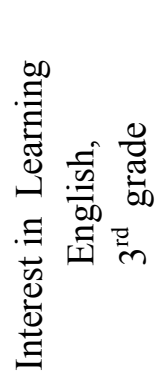 } & Item & STD & $\bar{D}$ & SLD & SLA & $\overline{\mathrm{A}}$ & STA & Mean & $\mathrm{SD}$ \\
\hline & 11 & 0 & 0 & 3 & 5 & 10 & 25 & 5.33 & 0.94 \\
\hline & 16 & 0 & 0 & 6 & 8 & 7 & 22 & 5.05 & 1.33 \\
\hline & 20 & 0 & 0 & 2 & 6 & 12 & 23 & 5.30 & 0.88 \\
\hline & 22 & 0 & 0 & 2 & 4 & 13 & 24 & 5.37 & 0.84 \\
\hline & Total & 0 & 0 & 13 & 23 & 42 & 94 & 5.27 & \\
\hline & & $0 \%$ & $0 \%$ & $7.5 \%$ & $13.3 \%$ & $24.5 \%$ & $54.7 \%$ & & \\
\hline
\end{tabular}

The overall mean of 5.27 suggests that participants educating in $3^{\text {rd }}$ grade of high school expressed positive attitudes towards learning English. More than 95\% of them believed they would learn English even if it were not offered as an obligatory course in the schools (Item 22). They also attached great important to learning English and wished they could watch English movies without the need to use Persian subtitles. Table 6 indicates how interested $4^{\text {th }}$ grade subjects are in learning English.

Table 6. Descriptive statistics for Component $1,4^{\text {th }}$ grade participants

\begin{tabular}{|c|c|c|c|c|c|c|c|c|c|}
\hline \multirow{7}{*}{ 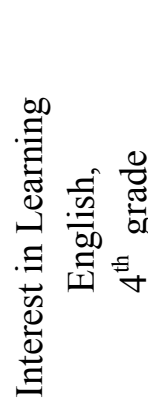 } & Item & STD & $\mathrm{D}$ & SLD & SLA & $\overline{\mathrm{A}}$ & STA & Mean & $\mathrm{SD}$ \\
\hline & 11 & 0 & 0 & 2 & 9 & 12 & 18 & 5.12 & 0.92 \\
\hline & 16 & 0 & 0 & 3 & 9 & 9 & 20 & 5.12 & 1.00 \\
\hline & 20 & 0 & 0 & 3 & 6 & 11 & 21 & 5.22 & 0.96 \\
\hline & 22 & 0 & 0 & 5 & 5 & 16 & 15 & 5.00 & 1.00 \\
\hline & Total & 0 & 0 & 13 & 29 & 48 & 74 & 5.11 & \\
\hline & & $0 \%$ & $0 \%$ & $8 \%$ & $17.7 \%$ & $29.3 \%$ & $45 \%$ & & \\
\hline
\end{tabular}

Not unlike participants in $1^{\text {st }}, 2^{\text {nd }}$ and $3^{\text {rd }}$ grades, the $4^{\text {th }}$ grade subjects also demonstrated high interest in learning English; about 92 percent of them confirmed their enthusiasm in English learning. They wished they could watch English movies without the need to use Persian subtitles (Item 22) and believed that English learning was important for them (Item 11). Absence of any remarkable deviation in the amount of overall means among the 4 grades (1st grade $=$ $5.24,2^{\text {nd }}$ grade $5.20,3^{\text {rd }}$ grade $=5.27$, and $4^{\text {th }}$ grade $\left.=5.11\right)$ indicates the fact that students educating in all grades of high school had positive attitudes towards learning English. The one factor analysis of variance (ANOVA) was run in order to show whether the degrees of students' interest educating in the four grades were significantly different.

Table 7. One factor ANOVA for Component 1

\begin{tabular}{|c|c|c|c|c|c|c|}
\hline & & $\begin{array}{l}\text { Sum } \\
\text { Squares }\end{array}$ & of $\mathrm{df}$ & $\begin{array}{l}\text { Mean } \\
\text { Square }\end{array}$ & $\mathrm{F}$ & Sig. \\
\hline \multirow[t]{4}{*}{ Interest } & Between & 8.181 & 3 & 2.727 & .209 & .890 \\
\hline & Groups & & & & & \\
\hline & Within Groups & 2113.753 & 162 & 13.048 & & \\
\hline & Total & 2121.934 & 165 & & & \\
\hline
\end{tabular}

Considering the data shown in Table $7(\mathrm{~F}=0.209, \mathrm{P}>0.05)$, it could be seen that there was no significant difference among the students of the four grades in terms of the degree of interest in learning English. 


\subsection{Component 2, Integrative motivation}

Unlike participants' attitudes towards Component 1, which suggested their high interest in English learning, they demonstrated strong tendencies toward integrative motivation in some grades. Table 8 indicates the way $1^{\text {st }}$ grade participants responded to the items investigating their integrativeness.

Table 8. Descriptive statistics for Component $2,1^{\text {st }}$ grade participants

\begin{tabular}{|c|c|c|c|c|c|c|c|c|c|}
\hline \multirow{13}{*}{ 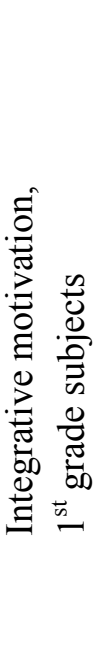 } & Item & STD & $\mathrm{D}$ & SLD & $\overline{\text { SLA }}$ & $\mathrm{A}$ & STA & Mean & $\mathrm{SD}$ \\
\hline & 1 & 0 & 1 & 3 & 9 & 20 & 10 & 4.81 & 0.95 \\
\hline & 4 & 0 & 3 & 2 & 10 & 16 & 12 & 4.78 & 1.03 \\
\hline & 9 & 0 & 3 & 5 & 8 & 17 & 10 & 4.60 & 1.17 \\
\hline & 12 & 0 & 1 & 7 & 7 & 12 & 16 & 4.81 & 1.18 \\
\hline & 13 & 0 & 2 & 3 & 13 & 17 & 8 & 4.60 & 1.02 \\
\hline & 14 & 0 & 3 & 6 & 8 & 15 & 11 & 4.58 & 1.22 \\
\hline & 15 & 0 & 1 & 10 & 7 & 9 & 16 & 4.67 & 1.26 \\
\hline & 19 & 0 & 1 & 13 & 10 & 14 & 5 & 4.21 & 1.08 \\
\hline & 21 & 2 & 4 & 14 & 9 & 11 & 3 & 3.74 & 1.26 \\
\hline & 26 & 0 & 0 & 7 & 6 & 16 & 14 & 4.86 & 1.06 \\
\hline & Total & 2 & 19 & 70 & 87 & 147 & 105 & 4.57 & \\
\hline & & $.4 \%$ & $4.5 \%$ & $16.2 \%$ & $20.2 \%$ & $34.2 \%$ & $24.5 \%$ & & \\
\hline
\end{tabular}

The data in table 8 suggest that $78.9 \%$ of respondents were integratively motivated and believed that the ability to communicate with foreigners and express thoughts orally is of high importance for them. The overall mean of 4.57 demonstrates the fact that participants educating in $1^{\text {st }}$ grade of high school have integrative orientations. Items 1,12 , and 26 received the highest percentage of agreement (more than 81.4\%) as well as means, which referred to subjects' wish to have oral discussions in the classroom, to spend their English learning time in language institutes rather than schools, and to be able to communicate with different people in different parts of the world. Item 21 is the only item with almost the same percentage of agreement (53.5\%) and disagreement (46.5\%) which referred to participants' wish to learn English in order to get familiar with American and British cultures. Table 9 shows $2^{\text {nd }}$ grade participants' integrativeness.

Table 9. Descriptive statistics for Component $2,2^{\text {nd }}$ grade participants

\begin{tabular}{|c|c|c|c|c|c|c|c|c|c|}
\hline & Item & STD & $\mathrm{D}$ & SLD & SLA & $\overline{\mathrm{A}}$ & STA & Mean & SD \\
\hline & 1 & 0 & 2 & 4 & 9 & 20 & 4 & 4.51 & 0.99 \\
\hline \multirow{11}{*}{ 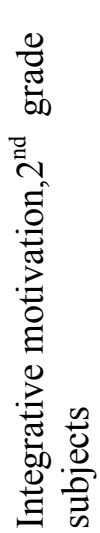 } & 4 & 1 & 2 & 4 & 11 & 10 & 11 & 4.54 & 1.29 \\
\hline & 9 & 0 & 2 & 6 & 9 & 14 & 8 & 4.51 & 1.14 \\
\hline & 12 & 0 & 3 & 6 & 7 & 9 & 14 & 4.64 & 1.32 \\
\hline & 13 & 1 & 4 & 3 & 10 & 13 & 8 & 4.38 & 1.33 \\
\hline & 14 & 0 & 4 & 7 & 7 & 12 & 9 & 4.38 & 1.31 \\
\hline & 15 & 1 & 2 & 6 & 8 & 7 & 15 & 4.62 & 1.40 \\
\hline & 19 & 0 & 2 & 11 & 10 & 12 & 4 & 4.13 & 1.10 \\
\hline & 21 & 1 & 4 & 13 & 8 & 10 & 3 & 3.79 & 1.23 \\
\hline & 26 & 0 & 2 & 5 & 6 & 14 & 12 & 4.74 & 1.18 \\
\hline & Total & 4 & 27 & 65 & 85 & 121 & 88 & 4.42 & \\
\hline & & $1 \%$ & $7 \%$ & $16.7 \%$ & $21.8 \%$ & $31 \%$ & $22.5 \%$ & & \\
\hline
\end{tabular}

Table 9 indicates that most of the subjects in second grade of high school (74.8\%) believed in their integrativeness, the fact which also satisfied the condition for $1^{\text {st }}$ grade ones. Item 26 received the highest percentages of agreement $(82 \%)$ and also amount of mean (4.74) among items investigating integrative motivation of participants, which referred to their being eager to learn English in order to be able to communicate with people living in different parts of the world. Item 12 was also one of the items which received a high degree of agreement in the eyes of $2^{\text {nd }}$ grade participants $\left(\bar{x}_{12}=4.64\right)$. It investigated whether the students preferred to spend their English learning time in language institutes rather than schools. About $70 \%$ of $2^{\text {nd }}$ grade participants thought so. Getting familiar with American and British cultures (Item 21 ) was of lowest importance among items and a remarkable percentage of participants (46\%) disagreed with it. Table 10 depicts the way $3^{\text {rd }}$ grade participants responded to items on Component 2. 
Table 10. Descriptive statistics for Component $2,3^{\text {rd }}$ grade participants

\begin{tabular}{|c|c|c|c|c|c|c|c|c|c|}
\hline \multirow{13}{*}{ 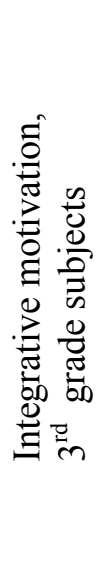 } & Item & STD & $\mathrm{D}$ & SLD & SLA & $\mathrm{A}$ & STA & Mean & $\mathrm{SD}$ \\
\hline & 1 & 3 & 6 & 10 & 5 & 10 & 9 & 3.93 & 1.59 \\
\hline & 4 & 4 & 7 & 8 & 7 & 10 & 7 & 3.77 & 1.60 \\
\hline & 9 & 4 & 8 & 6 & 10 & 8 & 7 & 3.72 & 1.59 \\
\hline & 12 & 2 & 8 & 12 & 3 & 7 & 11 & 3.88 & 1.63 \\
\hline & 13 & 1 & 12 & 4 & 10 & 13 & 3 & 3.72 & 1.40 \\
\hline & 14 & 2 & 6 & 11 & 7 & 10 & 7 & 3.88 & 1.40 \\
\hline & 15 & 4 & 8 & 10 & 6 & 6 & 9 & 3.67 & 1.65 \\
\hline & 19 & 3 & 9 & 11 & 7 & 8 & 5 & 3.53 & 1.48 \\
\hline & 21 & 4 & 8 & 12 & 9 & 9 & 1 & 3.33 & 1.32 \\
\hline & 26 & 2 & 6 & 10 & 11 & 7 & 7 & 3.84 & 1.43 \\
\hline & Total & 29 & 88 & 94 & 76 & 88 & 66 & 3.72 & \\
\hline & & $7 \%$ & $20 \%$ & $21 \%$ & $17 \%$ & $20 \%$ & $15 \%$ & & \\
\hline
\end{tabular}

The illustrated data in table 10 suggest a change in $3^{\text {rd }}$ grade participants' opinions about their integrativeness in comparison to $1^{\text {st }}$ and $2^{\text {nd }}$ grade ones. Despite the presence of high integrative motivation among $1^{\text {st }}$ and $2^{\text {nd }}$ grade participants where about $80 \%$ of participants confirmed their being integratively motivated, $48 \%$ of $3^{\text {rd }}$ grade participants believed that the ability to communicate in English and learn about new cultures is not of much necessity for them. Like participants educating in $1^{\text {st }}$ and $2^{\text {nd }}$ grades, $3^{\text {rd }}$ graders were unwilling to know much about new cultures in the US and England through learning English (Item 21). About 54\% of them were against the idea that they were learning English to use it in case they traveled abroad (Item19). A remarkable proportion of them believed that they did not have enough time to take English classes in language institutes (Item 15), and that oral presentations by students in the classroom were not pertinent classroom procedures (Item 9). Table 11 investigates the same issue about $4^{\text {th }}$ grade participants.

Table 11. Descriptive statistics for Component $2,4^{\text {th }}$ grade participants

\begin{tabular}{|c|c|c|c|c|c|c|c|c|c|}
\hline \multirow{13}{*}{ 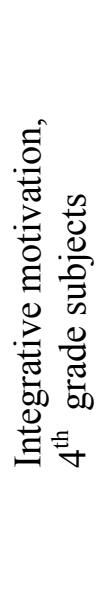 } & Item & STD & $\bar{D}$ & SLD & SLA & $\mathrm{A}$ & STA & Mean & $\mathrm{SD}$ \\
\hline & 1 & 5 & 13 & 14 & 3 & 2 & 4 & 2.90 & 1.41 \\
\hline & 4 & 8 & 13 & 9 & 5 & 5 & 1 & 2.73 & 1.37 \\
\hline & 9 & 9 & 11 & 10 & 4 & 3 & 4 & 2.83 & 1.56 \\
\hline & 12 & 7 & 12 & 12 & 2 & 1 & 7 & 2.98 & 1.65 \\
\hline & 13 & 3 & 16 & 7 & 8 & 5 & 2 & 3.05 & 1.35 \\
\hline & 14 & 5 & 9 & 15 & 5 & 4 & 3 & 3.07 & 1.38 \\
\hline & 15 & 6 & 9 & 11 & 9 & 0 & 6 & 3.15 & 1.54 \\
\hline & 19 & 8 & 8 & 14 & 5 & 2 & 4 & 2.93 & 1.49 \\
\hline & 21 & 6 & 10 & 10 & 10 & 5 & 0 & 2.95 & 1.26 \\
\hline & 26 & 5 & 10 & 11 & 8 & 4 & 3 & 3.12 & 1.41 \\
\hline & Total & 62 & 111 & 113 & 59 & 31 & 34 & 2.97 & \\
\hline & & $15.3 \%$ & $27 \%$ & $27.6 \%$ & $14.3 \%$ & $7.6 \%$ & $8.2 \%$ & & \\
\hline
\end{tabular}

Table 10 shows that participants in $4^{\text {th }}$ grade of high school indicated a completely distinctive percentage of integrativeness in comparison to other grades especially the ones in $1^{\text {st }}$ and $2^{\text {nd }}$ grades in that at least more than half of participants in other grades agreed that they had integrative motivations, but $69.9 \%$ of participants educating in $4^{\text {th }}$ grade were not integratively motivated and eager to get communicative and interactive abilities. More specifically about $75.6 \%$ of participants preferred to learn English in schools rather than language institutes (Item 12), while it is believed that very little attention is paid to communicative skills in schools in Iran. Furthermore, they were not for with having free discussions in classrooms (Item 1), and the ability to communicate with other people from different parts of the world was not of much importance for them (Item 4). The ANOVA summary table below indicates whether there was any significant difference among the grades in terms of their integrativeness.

Table 12. One factor ANOVA for Component 2

\begin{tabular}{lllllll}
\hline & & $\begin{array}{l}\text { Sum } \\
\text { Squares }\end{array}$ & of & $\begin{array}{l}\text { Mean } \\
\text { Square }\end{array}$ & F & Sig. \\
\hline Integrativene & Between & 6639.850 & 3 & 2213.283 & 26.160 & .000 \\
& $\begin{array}{l}\text { Groups } \\
\text { Within Groups }\end{array}$ & 13706.342 & 162 & 84.607 & & \\
& Total & 20346.193 & 165 & & & \\
\hline
\end{tabular}


As the data in Table 12 indicate, $F(3,162)=26.160 ; p<0.05$. This suggests that there is a highly significant difference among the four groups in terms of their integrativeness. However, it does not state where the significance lies. This issue could be tackled through running multiple pair-wise comparisons between groups, using a Tukey post hoc test.

Table 13. Multiple Pair-wise Comparisons between the four grades for Component 2

\begin{tabular}{|c|c|c|c|c|c|c|c|}
\hline \multirow[t]{2}{*}{ Variable } & $\begin{array}{l}\text { (I) } \\
\text { Grade }\end{array}$ & $\begin{array}{l}\text { (J) } \\
\text { Grade }\end{array}$ & $\begin{array}{l}\text { Mean } \\
\text { Differenc }\end{array}$ & $\begin{array}{l}\text { Std. } \\
\text { Error }\end{array}$ & Sig. & \multicolumn{2}{|l|}{ Interval } \\
\hline & & & $\begin{array}{l}\text { e } \\
\text { (I-J) }\end{array}$ & & & $\begin{array}{l}\text { Lower } \\
\text { Bound }\end{array}$ & $\begin{array}{l}\text { Upper } \\
\text { Bound }\end{array}$ \\
\hline Integrativen & $1 \mathrm{st}$ & 2nd & 1.39475 & 2.033 & .902 & -3.8852 & 6.6747 \\
\hline \multirow[t]{20}{*}{ ess } & Grade & Grade & & 97 & & & \\
\hline & & $3 r d$ & $8.37209^{*}$ & 1.983 & .000 & 3.2225 & 13.5217 \\
\hline & & Grade & & 74 & & & \\
\hline & & $\begin{array}{l}4 \text { th } \\
\text { grade }\end{array}$ & $15.94385^{*}$ & $\begin{array}{l}2.007 \\
78\end{array}$ & .000 & 10.7318 & 21.1558 \\
\hline & $2 \mathrm{nd}$ & $1 \mathrm{st}$ & -1.39475 & 2.033 & .902 & -6.6747 & 3.8852 \\
\hline & Grade & Grade & & 97 & & & \\
\hline & & $3 \mathrm{rd}$ & $6.97734^{*}$ & 2.033 & .004 & 1.6974 & 12.2573 \\
\hline & & Grade & & 97 & & & \\
\hline & & $\begin{array}{l}\text { 4th } \\
\text { grade }\end{array}$ & $14.54909^{*}$ & $\begin{array}{l}2.057 \\
43\end{array}$ & .000 & 9.2082 & 19.8900 \\
\hline & $3 r d$ & $1 \mathrm{st}$ & $-8.37209^{*}$ & 1.983 & .000 & -13.5217 & -3.2225 \\
\hline & Grade & Grade & & 74 & & & \\
\hline & & $2 \mathrm{nd}$ & $-6.97734^{*}$ & 2.033 & .004 & -12.2573 & -1.6974 \\
\hline & & Grade & & 97 & & & \\
\hline & & $\begin{array}{l}4 \text { th } \\
\text { grade }\end{array}$ & $7.57175^{*}$ & $\begin{array}{l}2.007 \\
78\end{array}$ & .001 & 2.3598 & 12.7838 \\
\hline & 4 th & $1 \mathrm{st}$ & - & 2.007 & .000 & -21.1558 & -10.7318 \\
\hline & grade & Grade & $15.94385^{*}$ & 78 & & & \\
\hline & & 2nd & - & 2.057 & .000 & -19.8900 & -9.2082 \\
\hline & & Grade & $14.54909^{*}$ & 43 & & & \\
\hline & & $3 r d$ & $-7.57175^{*}$ & 2.007 & .001 & -12.7838 & -2.3598 \\
\hline & & Grade & & 78 & & & \\
\hline
\end{tabular}

Table 13 shows all the possible pair-wise comparisons for our four groups of participants. We can see from the results in the first row that in terms of integrativeness, the $1^{\text {st }}$ graders were significantly different from $3^{\text {rd }}$ and $4^{\text {th }}$ graders as the $p$ values are small and less than 0.05 . No significant difference was found between $1^{\text {st }}$ and $2^{\text {nd }}$ graders as $\mathrm{P}<0.05$. In the second row, a comparison is made between $2^{\text {nd }}$ grade students and the rest educating in other grades. The asterisks $(*)$ by the value of mean differences indicate the differences between grades are significant; hence the mean difference of $2^{\text {nd }}$ graders and $3^{\text {rd }}$ grades $(6.97734)$, and also the mean difference of $2^{\text {nd }}$ grades and $4^{\text {th }}$ graders $(14.54909)$ were significantly different. Based on the data in the third row, the difference between means of $3^{\text {rd }}$ graders and $4^{\text {th }}$ graders (7.57175) was significant. To cut a long story short, the degree of integrativeness of $1^{\text {st }}$ and $2^{\text {nd }}$ graders was significantly different from that of $3^{\text {rd }}$ and $4^{\text {th }}$ graders, and also $3^{\text {rd }}$ graders had significantly different degree of integrativeness in comparison to $4^{\text {th }}$ graders.

\subsection{Component 3, Instrumental motivation}

Table 14 indicates the way first grade participants responded to the items investigating their instrumental motivation. 
Table 14. Descriptive statistics for Component $3,1^{\text {st }}$ grade participants

\begin{tabular}{|c|c|c|c|c|c|c|c|c|c|}
\hline \multirow{8}{*}{ 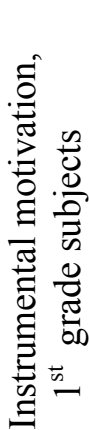 } & Item & $\begin{array}{l}\text { STD } \\
\end{array}$ & $\mathrm{D}$ & SLD & SLA & $\mathrm{A}$ & STA & Mean & SD \\
\hline & 5 & 0 & 0 & 0 & 7 & 20 & 16 & 5.21 & 0.70 \\
\hline & 8 & 0 & 0 & 0 & 11 & 13 & 19 & 5.19 & 0.82 \\
\hline & 17 & 0 & 0 & 0 & 2 & 17 & 24 & 5.51 & 0.59 \\
\hline & 23 & 0 & 0 & 0 & 4 & 14 & 25 & 5.49 & 0.66 \\
\hline & 25 & 0 & 4 & 8 & 8 & 14 & 9 & 4.37 & 1.27 \\
\hline & Total & 0 & 4 & 8 & 32 & 78 & 93 & 5.15 & \\
\hline & & $0 \%$ & $1.8 \%$ & $3.7 \%$ & $14.8 \%$ & $36.2 \%$ & $43.5 \%$ & & \\
\hline
\end{tabular}

The illustrated data in Table 14 suggest the high instrumental tendencies of first grade participants. They confirmed the high importance and vital role of learning English in their success in Iranian UEE, in finding a suitable job, and also in improving their educational levels. The overall mean of 5.15 out of 6 shows their high instrumental motivation. The interesting fact about the gathered data was the point that participants showed disagreements for neither of items except for Item 25 which was meant to investigate whether participants believed in the influence of English knowledge on the amount of money they would receive as salary in their would-be careers. About 6 percent of the participants denied any relation between English knowledge and amount of income they would earn. Table 15 shows the same component about $2^{\text {nd }}$ grade participants.

Table 15. Descriptive statistics for Component $3,2^{\text {nd }}$ grade participants

\begin{tabular}{|c|c|c|c|c|c|c|c|c|c|}
\hline \multirow{8}{*}{ 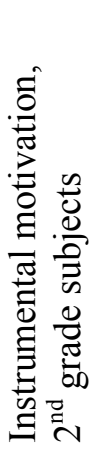 } & Item & STD & $\bar{D}$ & $\overline{\mathrm{SLD}}$ & SLA & $\bar{A}$ & STA & Mean & $\mathrm{SD}$ \\
\hline & 5 & 0 & 0 & 0 & 4 & 21 & 14 & 5.26 & 0.63 \\
\hline & 8 & 0 & 0 & 0 & 1 & 21 & 17 & 5.41 & 0.54 \\
\hline & 17 & 0 & 0 & 0 & 2 & 17 & 20 & 5.46 & 0.60 \\
\hline & 23 & 0 & 0 & 0 & 4 & 14 & 21 & 5.44 & 0.68 \\
\hline & 25 & 0 & 1 & 8 & 8 & 12 & 10 & 4.56 & 1.16 \\
\hline & Total & 0 & 1 & 8 & 19 & 85 & 82 & 5.22 & \\
\hline & & $0 \%$ & $0.5 \%$ & $4.1 \%$ & $9.7 \%$ & $43.5 \%$ & $42.2 \%$ & & \\
\hline
\end{tabular}

The data in Table 15 signify $2^{\text {nd }}$ grade participants' agreement on their tendencies toward instrumentality. Item 17 received the highest degree of agreement among the items investigating the instrumental motivation of subjects. The high mean for Item 17 (5.44) shows that participants strongly believed that learning English can remarkably affect their educational level. All of the responders believed that better occupational opportunities are offered to those who have enough English knowledge (Item 8). Like participants in first grade, the second graders showed disagreements only for Item 25 . Table 16 indicates the frequency and descriptive statistics for instrumental motivation of $3^{\text {rd }}$ grade participants.

Table 16. Descriptive statistics for Component $3,3^{\text {rd }}$ grade participants

\begin{tabular}{|c|c|c|c|c|c|c|c|c|c|}
\hline \multirow{8}{*}{ 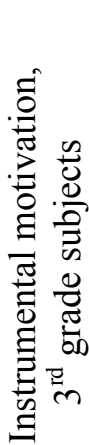 } & Item & STD & D & SLD & SLA & A & STA & Mean & SD \\
\hline & 5 & 0 & 0 & 0 & 5 & 16 & 22 & 5.40 & 0.69 \\
\hline & 8 & 0 & 0 & 0 & 7 & 17 & 19 & 5.28 & 0.73 \\
\hline & 17 & 0 & 0 & 0 & 0 & 13 & 30 & 5.70 & 0.46 \\
\hline & 23 & 0 & 0 & 0 & 2 & 18 & 23 & 5.49 & 0.59 \\
\hline & 25 & 0 & 3 & 6 & 6 & 16 & 12 & 4.49 & 1.23 \\
\hline & Total & 0 & 3 & 6 & 20 & 80 & 106 & 5.27 & \\
\hline & & $0 \%$ & $1.4 \%$ & $2.8 \%$ & $9.3 \%$ & $37.2 \%$ & $49.3 \%$ & & \\
\hline
\end{tabular}

The results collected from $3^{\text {rd }}$ grade participants were not much different from $1^{\text {st }}$ and $2^{\text {nd }}$ grade participants. In other words, high instrumental orientation was also indicated by $3^{\text {rd }}$ grade participants. They almost strongly agreed that English learning would affect their educational level (Item 17). All of the subjects agreed that learning English would provide them with a successful educational life as well as good job opportunities in future (Item 23). No one disagreed with the fact that answering English questions of UEE correctly would facilitate their acceptance in highly prestigious 
universities (Item 5). The direct effect of English knowledge on the amount of salary they would receive (Item 25) was the only case which received some amount of disagreement (about $21 \%$ ). Instrumentality of $4^{\text {th }}$ grade participants is indicated in Table 17.

Table 17. Descriptive statistics for Component $3,4^{\text {th }}$ grade participants

\begin{tabular}{|c|c|c|c|c|c|c|c|c|c|}
\hline \multirow{8}{*}{ 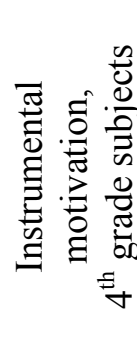 } & Item & STD & $\mathrm{D}$ & SLD & SLA & $\mathrm{A}$ & STA & Mean & $\mathrm{SD}$ \\
\hline & 5 & 0 & 0 & 0 & 2 & 16 & 23 & 5.51 & 0.59 \\
\hline & 8 & 0 & 0 & 0 & 5 & 10 & 26 & 5.51 & 0.71 \\
\hline & 17 & 0 & 0 & 0 & 3 & 13 & 25 & 5.54 & 0.63 \\
\hline & 23 & 0 & 0 & 0 & 4 & 13 & 24 & 5.49 & 0.67 \\
\hline & 25 & 0 & 3 & 7 & 9 & 10 & 12 & 4.51 & 1.28 \\
\hline & Total & 0 & 3 & 7 & 23 & 62 & 110 & 5.32 & \\
\hline & & $0 \%$ & $1.3 \%$ & $3.4 \%$ & $11.2 \%$ & $30.2 \%$ & $53.9 \%$ & & \\
\hline
\end{tabular}

As the overall mean in Table 17 (5.32) indicates, participants educating in $4^{\text {th }}$ grade of high school were instrumentally motivated in a remarkable manner. Like participants in other grades, they expressed some amount of disagreement only on Item 25, which referred to the direct effect of English knowledge on their future income. The ANOVA summary table below indicates whether there was any significant difference between the grades in terms of instrumentality.

Table 18. One factor ANOVA for Component 3

\begin{tabular}{lllllll}
\hline & & Sum of Squares & df & Mean Square & F & Sig. \\
\hline Componen & Between & 17.486 & 3 & 5.829 & .909 & .438 \\
t 3 & & & & & \\
& Groups & & & & \\
& Within & 1038.875 & 162 & 6.413 & & \\
& Groups & & & & & \\
& Total & 1056.361 & 165 & & & \\
\hline
\end{tabular}

As $\mathrm{F}(3,162)=0.909 ; \mathrm{P}>0.05$, it can be inferred that there was no significant difference among the groups. Therefore, it is possible to say that participants educating in different grades of high school showed strong instrumentality with no significant difference.

\subsection{Component 4, UEE effect on motivation of students in learning English}

The tables illustrating the data on this component investigate the probable effect of UEE on the priority of motivations in certain educational years. The items on Component 4 sought to investigate whether participants educating in different grades ignored acquiring communicative abilities in the favor of attaining necessary abilities in order to take the forthcoming UEE successfully. In other words, they sought to make it clear to what extent participants' degree of concern for the Iranian UEE could be a reason for their instrumental motivation to take priority over their integrative motivation. Table 19 shows this issue about $1^{\text {st }}$ grade participants.

Table 19. Descriptive statistics for Component $4,1^{\text {st }}$ grade participants

\begin{tabular}{|c|c|c|c|c|c|c|c|c|c|}
\hline \multirow{10}{*}{ 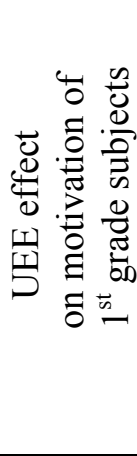 } & Item & STD & $\mathrm{D}$ & SLD & SLA & $\bar{A}$ & STA & Mean & $\mathrm{SD}$ \\
\hline & 2 & 10 & 16 & 7 & 6 & 4 & 0 & 2.49 & 1.26 \\
\hline & 3 & 7 & 12 & 7 & 11 & 5 & 1 & 2.95 & 1.37 \\
\hline & 6 & 12 & 15 & 10 & 2 & 4 & 0 & 2.33 & 1.21 \\
\hline & 7 & 8 & 17 & 10 & 5 & 3 & 0 & 2.49 & 1.14 \\
\hline & 10 & 6 & 16 & 15 & 3 & 3 & 0 & 2.56 & 1.05 \\
\hline & 18 & 12 & 13 & 12 & 3 & 2 & 1 & 2.37 & 1.23 \\
\hline & 24 & 13 & 15 & 11 & 3 & 1 & 0 & 2.16 & 1.02 \\
\hline & Total & 68 & 104 & 72 & 33 & 22 & 2 & 2.47 & \\
\hline & & $22.6 \%$ & $34.6 \%$ & $23.9 \%$ & $11 \%$ & $7.3 \%$ & $0.6 \%$ & & \\
\hline
\end{tabular}

The data in Table 19 indicate that instrumental motivation is not given priority by $81.1 \%$ of subjects educating in $1^{\text {st }}$ grade of high school. More than $90 \%$ of them believed, in that period of time, they were not to be concerned about being admitted in universities as much as getting communicative skills (Item 6). More than 95\% of them also preferred to spend their English learning time by chatting with English speakers rather than reviewing the English questions of 
UEEs in previous years (Item 24). Table 20 indicates the way $2^{\text {nd }}$ grade participants responded to the items on Component 4.

Table 20. Descriptive statistics for Component $4,2^{\text {nd }}$ grade participants

\begin{tabular}{|c|c|c|c|c|c|c|c|c|c|}
\hline \multirow{10}{*}{ 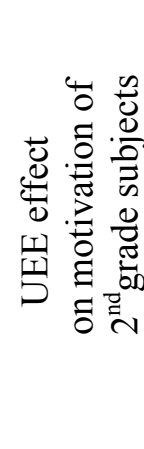 } & Item & STD & $\mathrm{D}$ & SLD & SLA & $\bar{A}$ & STA & Mean & $\mathrm{SD}$ \\
\hline & 2 & $\overline{6}$ & 11 & $\overline{7}$ & 8 & 6 & 1 & 3.00 & 1.41 \\
\hline & 3 & 6 & 7 & 10 & 8 & 6 & 2 & 3.18 & 1.46 \\
\hline & 6 & 7 & 8 & 8 & 8 & 5 & 3 & 3.13 & 1.54 \\
\hline & 7 & 10 & 9 & 4 & 7 & 8 & 1 & 2.92 & 1.59 \\
\hline & 10 & 5 & 11 & 9 & 7 & 5 & 2 & 3.05 & 1.41 \\
\hline & 18 & 9 & 8 & 8 & 7 & 4 & 3 & 2.95 & 1.57 \\
\hline & 24 & 5 & 12 & 7 & 8 & 6 & 1 & 3.03 & 1.38 \\
\hline & Total & 48 & 66 & 53 & 53 & 40 & 13 & 3.03 & \\
\hline & & $17.5 \%$ & $24.2 \%$ & $19.5 \%$ & $19.5 \%$ & $14.6 \%$ & $4.7 \%$ & & \\
\hline
\end{tabular}

Table 20 suggests that more than $61 \%$ of the participants did not have positive attitudes towards putting their instrumental motivation in priority. Items 7 and 18 received the highest degree of disagreement among items $\left(\overline{\mathrm{x}}_{7}=2.92\right.$ and $\bar{x}_{18}=2.95$ ), which respectively referred to participants' preference to concentrate on reading comprehension skills and cloze tests rather than communicative skills and to invest their English learning time in learning grammatical tips and answering English tests. The way $3^{\text {rd }}$ grade subjects responded to items on Component 4 is illustrated in Table 21 .

Table 21. Descriptive statistics for Component $4,3^{\text {rd }}$ grade participants

\begin{tabular}{|c|c|c|c|c|c|c|c|c|c|}
\hline \multirow{10}{*}{ 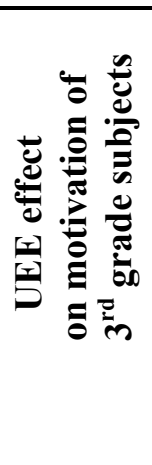 } & Item & STD & $\bar{D}$ & SLD & SLA & $\mathbf{A}$ & STA & Mean & SD \\
\hline & 2 & 2 & 3 & 4 & 14 & 11 & 9 & 4.30 & 1.35 \\
\hline & 3 & 3 & 4 & 4 & 10 & 13 & 10 & 4.33 & 1.47 \\
\hline & 6 & 3 & 3 & 6 & 11 & 12 & 8 & 4.16 & 1.44 \\
\hline & 7 & 4 & 6 & 4 & 10 & 12 & 7 & 3.95 & 1.57 \\
\hline & 10 & 4 & 6 & 7 & 6 & 12 & 8 & 3.93 & 1.62 \\
\hline & 18 & 1 & 6 & 5 & 11 & 10 & 10 & 4.23 & 1.42 \\
\hline & 24 & 1 & 5 & 4 & 12 & 13 & 8 & 4.28 & 1.33 \\
\hline & Total & 18 & 33 & 34 & 74 & 83 & 60 & 4.16 & \\
\hline & & $6 \%$ & $10.9 \%$ & $11 \%$ & $24.5 \%$ & $27.6 \%$ & $20 \%$ & & \\
\hline
\end{tabular}

Tables 19 and 20 revealed that instrumental motivation was not given priority by most of subjects educating in $1^{\text {st }}$ and $2^{\text {nd }}$ grades of high school. On the contrary, the results in Table 21 indicate that instrumental motivation was the dominant motivation type among $3^{\text {rd }}$ grade participants. More than $72 \%$ of them wished to devote themselves to language learning procedures which would facilitate their acceptance in universities. For instance, more than $76 \%$ of them preferred to review English questions of UEEs in previous years rather than chat with English speakers (Item24). About $80 \%$ of them believed having free discussions in classrooms is wasting the time remained to 'UEE day' (Item 2). Table 22 illustrates the results on the same component taken by $4^{\text {th }}$ grade participants.

Table 22. Descriptive statistics for Component $4,4^{\text {th }}$ grade participants

\begin{tabular}{|c|c|c|c|c|c|c|c|c|c|}
\hline \multirow{10}{*}{ 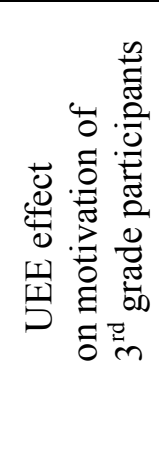 } & Item & STD & D & SLI & SLA & $\mathrm{A}$ & STA & Mean & SD \\
\hline & 2 & 0 & 1 & 3 & 10 & 12 & 15 & 4.90 & 1.06 \\
\hline & 3 & 0 & 1 & 3 & 10 & 9 & 18 & 4.98 & 1.10 \\
\hline & 6 & 0 & 3 & 1 & 11 & 14 & 12 & 4.76 & 1.13 \\
\hline & 7 & 0 & 4 & 4 & 8 & 12 & 13 & 4.63 & 1.29 \\
\hline & 10 & 0 & 3 & 5 & 7 & 16 & 10 & 4.61 & 1.20 \\
\hline & 18 & 0 & 2 & 3 & 9 & 11 & 16 & 4.88 & 1.16 \\
\hline & 24 & 0 & 2 & 2 & 9 & 16 & 12 & 4.83 & 1.07 \\
\hline & Total & 0 & 16 & 21 & 64 & 90 & 96 & 4.80 & \\
\hline & & $0 \%$ & $10.9 \%$ & $11 \%$ & $22.2 \%$ & $31.4 \%$ & $33.5 \%$ & & \\
\hline
\end{tabular}

As the results in Table 22 suggest, $4^{\text {th }}$ grade subjects were highly willing to invest their time in instrumentally-based activities. Between integrative and Instrumental-based activities, the latter was given priority by more than $87 \%$ of subjects educating in $4^{\text {th }}$ grade of high school. Item 3 received the highest amount of agreement $\left(\overline{\mathrm{x}}_{3}=4.98\right)$, where more than $90 \%$ of the subjects believed that their English teachers had to concentrate on teaching important grammatical tips rather than useful every day expressions (Item 3). The same number of subjects also thought having free discussions in 
the classroom would waste the time left to the UEE day (Item 2). The ANOVA summary table below indicates whether the way subjects in different grades prioritized their motivations on the basis of the degree of their concern for taking the Iranian UEE differed significantly.

Table 23. One factor ANOVA for Component 4

\begin{tabular}{|c|c|c|c|c|c|c|}
\hline & & $\begin{array}{ll}\text { Sum } & \text { of } \\
\text { Squares } & \\
\end{array}$ & $\mathrm{df}$ & $\begin{array}{l}\text { Mean } \\
\text { Square } \\
\end{array}$ & $\mathrm{F}$ & Sig. \\
\hline \multirow[t]{4}{*}{ UEE effect } & Between & 6804.460 & 3 & 2268.153 & 30.609 & .000 \\
\hline & Groups & & & & & \\
\hline & Within Groups & 12004.317 & 162 & 74.101 & & \\
\hline & Total & 18808.777 & 165 & & & \\
\hline
\end{tabular}

As the data in Table 23 indicate, $F(3,162)=30.609 ; p<0.05$. This suggests that there is a highly significant difference among groups in terms of the way they prioritized their motivations regarding the degree of concern for taking the UEE. Multiple pair-wise comparisons between groups were conducted to precisely indicate where these differences lie.

Table 24. Multiple Pair-wise Comparisons between the four grades for Component 4

\begin{tabular}{|c|c|c|c|c|c|c|c|}
\hline Dependent & (I) & (J) & Mean & Std. & Sig. & $95 \%$ & Confidence \\
\hline \multirow[t]{3}{*}{ Variable } & \multirow[t]{3}{*}{ Grade } & \multirow[t]{3}{*}{ Grade } & \multirow{3}{*}{$\begin{array}{l}\text { Difference } \\
(\mathrm{I}-\mathrm{J})\end{array}$} & \multirow[t]{3}{*}{ Error } & & \multicolumn{2}{|l|}{ Interval } \\
\hline & & & & & & Lower & Upper \\
\hline & & & & & & Bound & Bound \\
\hline \multirow[t]{24}{*}{ UEE effect } & $1 \mathrm{st}$ & 2 nd & -3.90757 & 1.9034 & .173 & -8.8488 & 1.0337 \\
\hline & Grade & Grade & & 9 & & & \\
\hline & & $3 \mathrm{rd}$ & $-11.79070^{*}$ & 1.8564 & .000 & -16.6099 & -6.9714 \\
\hline & & Grade & & 9 & & & \\
\hline & & 4 th & $-16.23653^{*}$ & 1.8789 & .000 & -21.1142 & -11.3589 \\
\hline & & grade & & 9 & & & \\
\hline & 2nd & 1 st & 3.90757 & 1.9034 & .173 & -1.0337 & 8.8488 \\
\hline & Grade & Grade & & 9 & & & \\
\hline & & $3 \mathrm{rd}$ & $-7.88312^{*}$ & 1.9034 & .000 & -12.8244 & -2.9418 \\
\hline & & Grade & & 9 & & & \\
\hline & & 4th & $-12.32896^{*}$ & 1.9254 & .000 & -17.3272 & -7.3307 \\
\hline & & grade & & 5 & & & \\
\hline & $3 \mathrm{rd}$ & 1 st & $11.79070^{*}$ & 1.8564 & .000 & 6.9714 & 16.6099 \\
\hline & Grade & Grade & & 9 & & & \\
\hline & & 2nd & $7.88312^{*}$ & 1.9034 & .000 & 2.9418 & 12.8244 \\
\hline & & Grade & & 9 & & & \\
\hline & & 4th & -4.44583 & 1.8789 & .088 & -9.3235 & .4318 \\
\hline & & grade & & 9 & & & \\
\hline & 4 th & 1 st & $16.23653^{*}$ & 1.8789 & .000 & 11.3589 & 21.1142 \\
\hline & grade & Grade & & 9 & & & \\
\hline & & 2 nd & $12.32896^{*}$ & 1.9254 & .000 & 7.3307 & 17.3272 \\
\hline & & Grade & & 5 & & & \\
\hline & & $3 \mathrm{rd}$ & 4.44583 & 1.8789 & .088 & -.4318 & 9.3235 \\
\hline & & Grade & & 9 & & & \\
\hline
\end{tabular}

*. The mean difference is significant at the 0.05 level

There are several comparisons made in Table 24. In the comparison between $1^{\text {st }}$ grade participants and other groups (first row), the asterisks by the values of the differences between $1^{\text {st }}$ graders' and $3^{\text {rd }}$ grades' means $(-11.79070)$ and also $1^{\text {st }}$ graders' and $4^{\text {th }}$ graders' means $(-16.23653)$ indicate that $1^{\text {st }}$ grade participants' prioritization of their motivations 
was significantly different from that of $3^{\text {rd }}$ and $4^{\text {th }}$ grade subjects. The difference between means of $1^{\text {st }}$ grade and $2^{\text {nd }}$ grade participants (-3.90757) was not significant due to the fact that the $P$ value was larger than 0.05 . Regarding the data in second row, it can be suggested that $2^{\text {nd }}$ grade subjects prioritized their motivations differently in comparison to $3^{\text {rd }}$ and $4^{\text {th }}$ grade subjects, and the differences were significant $\left(p<0.05\right.$ in $2^{\text {nd }}-3^{\text {rd }}$ and $2^{\text {nd }}-4^{\text {th }}$ comparisons). Furthermore, the data in the third row indicate that the difference in the means of $3^{\text {rd }}$ and $4^{\text {th }}$ grades $(-4.44583)$ was not significant $(\mathrm{P}>0.05)$. In short, $1^{\text {st }}$ and $2^{\text {nd }}$ grade subjects' prioritization of their motivations was significantly different from that of $3^{\text {rd }}$ and $4^{\text {th }}$ graders.

Taking the data related to Component 4 into account, it is possible to claim that the participants studying in higher grades of high school show more concern about taking the UEE. The attained results on the 4 components revealed that $1^{\text {st }}$ and $2^{\text {nd }}$ participants were both instrumentally and integratively motivated but their degree of concern for acquiring communicative abilities surpassed their concern about UEE. Therefore, their integrative motivation was given priority. The high degree of concern for taking the UEE successfully among $3^{\text {rd }}$ and $4^{\text {th }}$ grade participants made them ignore expression of integrative motivation to learn English. It was also revealed that the more participants approach the day of taking the UEE, the less integrative motivation they express.

To cut a long story short, regarding the findings of the study on Component 1, it can be suggested that participants educating in High schools for the Gifted showed highly positive attitudes towards learning English, no matter in what grade they were educating. This is in line with the findings of the studies conducted by Gholami et al. (2012) and Vaezi (2008) who claimed the subjects of their studies were highly interested in learning English. The obtained data on Components 2 and 3 indicated that participants educating in different grades signified different motivational orientations. More specifically, $1^{\text {st }}$ and $2^{\text {nd }}$ graders were both instrumentally and integratively motivated, whereas $3^{\text {rd }}$ and $4^{\text {th }}$ grade subjects did not have integrative orientations and were instrumentally motivated in high manners. Such results are in disagreement with the results found by Gholami et al. (2012), Mehrpour \& Vojdani (2012) and Sheibani (2012) who believed the subjects of their studies had instrumental domination, and also with those found by Sayadian and Lashkarian (2009) and Sadighi and Maghsudi (2000) who claimed only a few participants in their studies were instrumentally motivated. However, the results attained on Components 2 and 3 are in consonance with the results of the studies which account for both instrumental and integrative motivations and take such a fact in to consideration that even in the same EFL or ESL contexts, learners would show different motivational orientations in order to learn a new language. Such results were revealed in the studies conducted by Moiinvaziri (2008) and Ebrahimi (2002). Meanwhile, the results on Component 4 designated that the high concern $3^{\text {rd }}$ and $4^{\text {th }}$ grade subjects have about taking the Iranian UEE makes them turn blind eyes to intercommunicative activities that could be fostered by integrative motivation, which is in alignment with the view of Vaezi (2008) on the most important problem Iranian high school students face to. He believed that Iranian students graduate from high schools with low interactive abilities in English.

\section{Conclusion}

This study was an attempt to study the attitudes of students educating in the High Schools for the Gifted towards learning English and to investigate their attitudes towards integrativeness and instrumentality. Furthermore, the influence of the Iranian University Entrance Exam on prioritization of their motivation type was investigated. The obtained results from the statistical analyses of the collected data revealed that participants educating in the four grades of high school showed positive attitudes towards English learning, and that $1^{\text {st }}$ and $2^{\text {nd }}$ grade subjects were both instrumentally and integratively motivated, whereas $3^{\text {rd }}$ and $4^{\text {th }}$ graders were instrumentally motivated. In addition, it became clear that the degree of concern about the Iranian UEE was more noticeable in higher grades, and consequently $1^{\text {st }}$ and $2^{\text {nd }}$ grade participants, unlike the $3^{\text {rd }}$ and $4^{\text {th }}$ graders, did not view English learning primarily as a gateway to success in getting university admissions but rather as a means of global communication. More specifically put, although $1^{\text {st }}$ and $2^{\text {nd }}$ graders were both instrumentally and integratively motivated, instrumental motivation was not the priority for them. It seems the increased degree of concern about the Iranian UEE could serve as a booster for gifted high school students to gradually leave their integrative motivation behind as they approach the day of taking the UEE due to the fact that no place has ever been set for assessment of applicants' communicative abilities in the English section of Iranian UEE. These findings have important implications for teacher and educators. Given the important role which integrative motivation could play in education, in general, and language education, in particular, teachers and educational authorities need to be mindful of the potential effects which their tests, especially high-stake ones, could have on students.

\section{References}

Al-Zubeiry, H. (2011). The socio-psychological orientations of Saudi learners of English as a foreign language. $\mathrm{Al}$ Qura University journal of languages and literature, 15, 34-50.

Basturk, S. (2011). Negative reflections of preparation process to the university entrance exam on students' mathematics learning. H. U. journal of education, 40, 69-79. 
Brown, H. D. (2007). Principles of Language Learning and Teaching, 5th edition. White

Plains, NY: Pearson Education Inc.

Chalak, A., \& Kassaian, Z. (2010). Motivation and attitudes of Iranian undergraduate EFL students towards learning English. GEMA Online TM Journal of Language Studies, 10(2), 37-56.

Chastain, K. (1988). Developing second language skills. Theory and practice, $3^{\text {rd }}$ edition. New York: Harcourt Brace and Javanovich.

Clement, R. et al. (1994). Motivation, self-confidence and group cohesion in the foreign language classroom. Language Learning, 44, 417-448.

Csizer, K., et al. (2006). Motivation, language attitudes and globalization: A Hungarian perspective. Clevedon, England: Multilingual Matters.

Dörnyei, Z. (1990). Conceptualizing motivation in foreign language learning. Language Learning, 40, 45-78.

Dörnyei, Z. (1994a). Motivation and motivating in the foreign language Classroom. Modern Language Journal, 78(3), 273-284.

Dörnyei, Z. (1998). Motivation in second and foreign language learning. Language Teaching, 31, 117-35.

Dörnyei, Z. (2001). Teaching and researching motivation. London: Longman.

Dörnyei, Z. (2006). Creating a motivating classroom environment. In J. Cummins and C. Davison (eds.), The Handbook of English Language Teaching. New York: Springer.

Dörnyei, Z., \& Ushioda. (2010). Teaching and researching motivation. London: Longman.

Ebrahimi, A. (2002). A comparative study of language learning strategies employed by bilinguals and monolinguals with reference to attitudes and motivation, unpublished Master Thesis, Tehran, Teacher training university, Iran.

Ehrman, M. (1996). An exploration of adult language learning motivation, self-efficacy, and anxiety. In J.L. Oxford (Ed.), Language Learning Motivation: Pathways to the New Century. Honolulu: University of Hawai'i Press.

Eslami Rasekh, A., \& Simin, Sh. (2012). Investigating EAP of Tourism in Iran: a Case Study of Students' Perception. English for Specific Purposes World, 36(12), 112- 138.

Farhadi, H., et al. (2003). Testing language skills. From theory to practice. Tehran: SAMT.

Finegan, E. (1999). Language: Its structure and use (3rd ed.). Harcourt Brace.

Gardner, R.C. (1985). Social psychology and language learning: The role of attitudes and motivation. London: Edward Arnold.

Gardner, R. C., \& Macintyre, P. D. (1993). On the measurement of affective variables in second language learning. Language Learning, 43(2), 157-194.

Gardner, R. C., \& Lambert, W. E. (1972). Attitudes and motivation in second language learning. Rowley, MA: Newbury House.

Ghanea, M., \& Zraat Pisheh,H. (2011). The relationship between learners' motivation (integrative and instrumental) and English proficiency among Iranian EFL learners. World academy of science, engineering and technology, 59, 458-464.

Gholami, R., \& Allahyar, N. (2012). Integrative motivation and essential determinant of achievement: A case of EFL high school students. World Applied Sciences Journal, 17(11), 1416-1424.

Kashi, M. (2009). The effect of Iranian EFL learners' motivation on their attitudes towards their English teachers (Unpublished master's thesis). Najaf Abad Azad University, Najaf Abad.

Kumaravadivelu, B. (2005). Understanding language teaching from method to post-method. London: Lawrence Erlbaum Associates.

Mckay, S., \& Rubdy, R. (2009). The social context of language teaching. In Long, M. H., \& Doughty, C. J. ( Eds.). The handbook of language teaching (pp. 9-25). West Sussex: Wiley-Blackwell.

Mehrpour, S., \& Vojdani, M. (2012). Globalization and EFL learning motivation: A new perspective on integrative vs. instrumental motivation among Iranian learners of English. Open Journal of Modern Linguistics, 2(2), 43-50.

Moiinvaziri, M. (2008). Motivational orientation in English language learning: A study of Iranian undergraduate students .Global practices of language teaching. Proceeding of International Online Language Conference (IOLC).Universal publishers. Boca Raton, Florida, US, 126-135.

Noels, K.A., et al. (1999). Perceptions of teacher communicative style and students' intrinsic and extrinsic motivation. Modern Language Journal, 83, 23-34.

Noels, K.A., et al. (2000). Why are you learning a second language? Motivation orientations and self-determination theory. Language Learning, 50, 57-85. 
Noels, K.A., et al. (2001). Intrinsic, extrinsic, and integrative orientations of French Canadian learners of English. Canadian Modern Language Review, 57, 424-442.

Oxford, L. (1996). Language Learning Motivation: Pathways to the New Century. Honolulu: University of Hawaii Press.

Ramage, K. (1990). Motivational factors and persistence in foreign language study. Language Learning, 40, 189-219.

Roohani, A. (2001). An investigation into EFL students' motivation in Shiraz stated and Islamic Azad University. Unpublished master's thesis. Shiraz University, Shiraz.

Sadighi, F., \& Maghsudi, N. (2000). The Relationship between Motivation and English proficiency among Iranian EFL Learners. Indian Journal of Applied Linguistics, 26, 39-52.

Salehi, H., \& Melor, Y. (2012). The wash-back effect of the Iranian universities entrance exam: Teachers' insights. GEMA Online TM Journal of Language Studies, 12(2), 609-628.

Sayadian, S., \& Lashkarian, A. (2009). Investigating Attitude and Motivation of Iranian University Learners Toward English as a Foreign Language, IABR and TLC Conference Proceedings, San Antonio, Texas, USA.

Scheideker, D., \& Freeman, W. (1999). Bringing out the Best in Students: How Legendary Teachers Motivate Kids. Thousand Oaks, CA: Corwin Press.

Sheibani, O. (2012). Language learning motivation among Iranian Undergraduate students. World Applied Sciences Journal, 19 (6), 838-846.

Tachibana, Y., et al. (1996). Attitudes and motivation for learning English: a cross-national comparison of Japanese and Chinese high school students. Psychological Reports, 79, 691-700.

Vaezi, Z. (2008). Language learning motivation among Iranian undergraduate students.

World Applied Sciences Journal, 5(1), 54-61.

Wharton, S., \& Race, P. (1999). 500 Tips for TESOL. London: Kogan Page.

$\mathrm{Wu}, \mathrm{X}$. (2003). Intrinsic motivation and young language learners: the impact of the classroom environment. System, 31, 501-517. 